\title{
Water Quality Assessment of the Morava e Binçës River Based on the Physicochemical Parameters and Water Quality Index
}

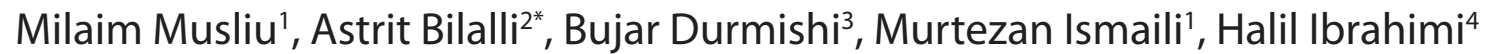 \\ 1 South East European University, Faculty of Contemporary Sciences and Technologies, Tetovë, Republic of \\ Macedonia \\ 2 University of Peja "Haxhi Zeka", Faculty of Agribusiness, Pejë, Kosovo \\ ${ }^{3}$ Faculty of Natural Sciences and Mathematics, State University of Tetova, llinden str n.n., Tetovo, Republic of \\ Macedonia \\ ${ }^{4}$ University of Prishtina "Hasan Prishtina", Faculty of Mathematics and Natural Sciences, Department of Biology, \\ Prishtina, Kosovo \\ * Corresponding author's e-mail: astritbilalli@yahoo.com
}

\begin{abstract}
The quality of surface waters is being impacted by the anthropogenic and natural pollution, thus limiting the usage of this water for drinking, industry, agriculture, recreation and other purposes. The water quality indices are intended to provide a single value for the water quality of a source or a stream that reduces the large amount of parameters in a simpler expression and enables an easy interpretation of the monitoring data. During 2017, seventeen physicochemical parameters were measured in spring, summer, autumn and winter, in five locations along the Morava e Binçës River in Kosovo. For the assessment we employed the Water Quality Index (WQI) which uses the physicochemical parameters for the evaluation of the water quality. The findings of this study ascertain that MB1 station had the best quality with a value of WQI 88 and is classified in the Good Category, whereas the lowest quality of water was found on in MB4 station with a value of WQI 65 and it is thus classified in the Fair Category. Finally, the average WQI was calculated for the entire measurement period and it resulted in a value of 77.60 indicating that the Morava e Binçës River waters belong to the Fair Category.
\end{abstract}

Keywords: Physicochemical parametres, River waters, Water Quality, WQI, Morava e Binçës

\section{INTRODUCTION}

One of the major world problems is a drastic reduction of the available water resources [Durmishi, 2005; Ismaili and Durmishi, 2006]. Nowadays, many people worldwide suffer from the lack of safe and quality water, which is essential for popular needs. In numerous countries, water resources are depleted faster than they can be replenished and not enough to meet the demands of modern human life. Environmental pollution and especially the contamination of water sources in this regard becomes an issue to be addressed immediately. The increased urbanization, industrialization, the modernization of agriculture and the increase in traffic all contribute to the global pollution, which in turn requires accurate monitoring and information about the quality of water resources. The concerns for the quality of water come from the global social trends, population growth and development activities, which have been the cause of pollution. Moreover, inadequate management of water systems can cause serious problems in the water availability and quality of water [Krishnan et al., 2007]. Hence, it is necessary to evaluate the quality of the river water.

Water quality can best be described by the physicochemical parameters and biological parameters. The physicochemical parameters play an important role in the system restoration maintenance and self-regulation of water quality [Barakat et al., 2012]. Some correlations between 
these parameters can be done and useful conclusions can be drawn to show the quality of water. The physicochemical parameters of water and the dependence of all life process of these factors make it desirable to take as an environment [Anbarasu and Anbuselvan, 2017]. A very powerful tool for water quality assessment is the Water Quality Index (WQI). WQI serves to sum up large quantities of water quality data under simple conditions (e.g. good, bad) for the management and public consistent reporting [Durmishi et al., 2012]. WQI represents a mere number of $0-100$, where a higher value indicates a better water quality and vice versa.

The purpose of this article was to evaluate the water quality of the Morava e Binçës river by measuring some physicochemical parameters and WQI.

\section{MATERIALS AND METHODS}

\section{Study area}

The basin of the Morava e Binçës River is located in the south and southeast of the Repub- lic of Kosova. This river is created by two other smaller rivers which flow to the northern slopes of Karadaku of Skopje. The length of the Morava e Binçës River in the territory of Kosova is around $60 \mathrm{~km}$ [MESP, 2015] with a surface of the basin $1,175 \mathrm{~km}^{2}$. In the upper part, the river is fast with a great tilt, deep and narrow bed where vertical erosion is emphasized. In the further course, this river passes through the Gjilan area with a length of $24 \mathrm{~km}$ [MESP, 2010]. In this part it has a wider bed and a smaller tilt.

\section{Physicochemical parameters}

The physicochemical parameters were measured during all four seasons of 2017. The parameters were measured in five stations (locations) in the mainstream of Morava e Binçës river. The locations were selected starting from the source area - the first locations in Korbliq (MB1), the second locations in Viti (MB2) the third locations in Uglare village (MB3), the fourth locations in Pogragjë (MB4) and the fifth locations in Dheu i Bardhë village (MB5). The first sampling stacion is located at the spring area of this river, while other sampling stations are located in the mid-

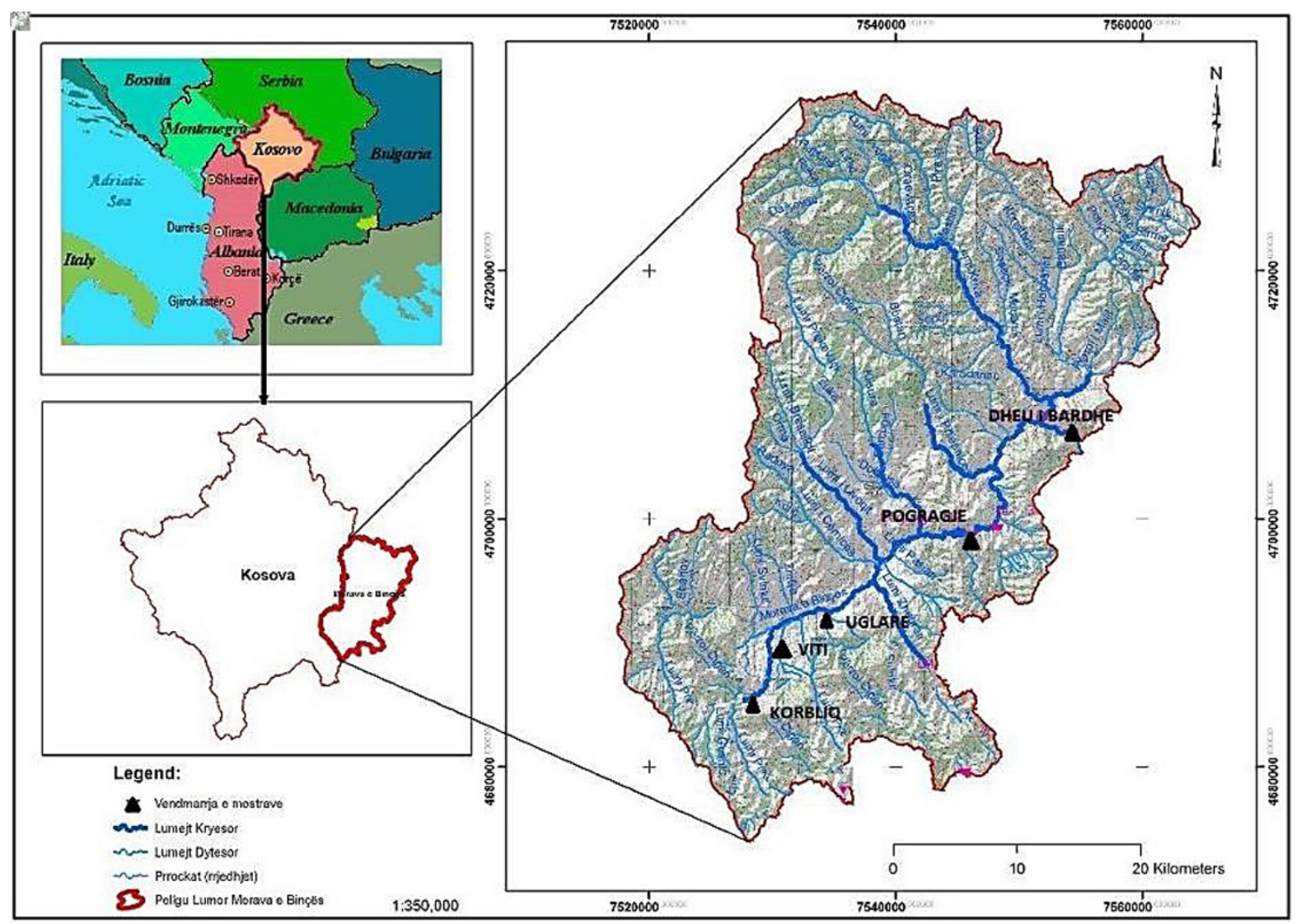

Figure 1. The Map of the Morava e Binçës River with indicated sampling stations 
stream and downstream area of the river where there is a serious discharge of different pollutants into the river.

\section{Water sample collection and analysis}

The water sampling for analysis is carried out by using equipment and containers based on the ISO 5667-6 standard, which sets the principles that will be applied in designing the sampling programs of sampling techniques and treatment of water samples taken from rivers as well as physical and chemical assessment and process. The samples were taken in four time periods: spring, summer, autumn and winter during 2017, in five stations (locations) in the mainstream of Morava e Binçës. At each station were measured seventeen physicochemical parameters.

The analyses of the samples taken from the water of Morava e Binçës were carried out in the laboratory of the Hydrometeorological Institute of Kosova in Prishtina. The water quality parameters were defined by using the following measuring equipment: WTW 350i for electrical conduct, AQUALITIC/PC COMPACT for turbidity, the measures for $\mathrm{pH}$ value were carried out with the HI $98130 \mathrm{pH}$-meter, the dissolved oxygen and oxygen saturation was performed with HI 9146, spectrophotometer detergents with the type of SECOMAN Pastel model UV, phosphates and ammonia with SECOMAN PRIM LIGHT, etc.

\section{RESULTS AND DISCUSSION}

The results of this research are presented in the Tables 1-2 and in Figures 2-5.

\section{Water Temperature (WT)}

The variation of WT concentration has been in the range of $7.50-25.30{ }^{\circ} \mathrm{C}$. The lowest value was measured in MB1 station (winter), while the highest one in MB2 station (summer). The average values in winter, spring, summer and autumn were $8.82,16.14,21.6$ and $14.00^{\circ} \mathrm{C}$ respectively, whereas the annual average with a standard deviation of $15.140 \pm 5.227^{\circ} \mathrm{C}$. The average values of WT in MB1-MB5 stations were 13.500, 15.775, $16.225,15.525$, and $14.825^{\circ} \mathrm{C}$, respectively. The WT values of Morava e Binçës basin resulted within the recommended values of GD161 regulation and the water of this river was classified as first class (Fig. 2).

\section{Turbidity (TUR)}

The concentration variation of TURB was in the range of 0.100-51.200 NTU unit. The lowest value was measured in MB1 station (winter), while the highest one in MB4 station (autumn). The average values in winter, spring, summer and autumn were $0.240,17.072,21.302$ and 21.386 NTU units, respectively, while the annual average with a standard deviation were $15.000 \pm 17.138$ NTU units. The average values of TUR in MB1-MB5 stations were 3.140, 4.205, 22.55, 29.65 , and 15.328 NTU units. The TUR values that exceeded the GD161 Regulation were 47.500 (MB3, summer), 32.100 (MB3, autumn), 28.800 (MB4, sprind), 38.800 (MB4, summer), 51.200 (MB4, autumn) and 34.300 (MB5, spring) NTU units. The TUR values in Morava e Binçës water were within the recommended values of GD161 regulation and the water of this river was classified as first class (Fig. 2).

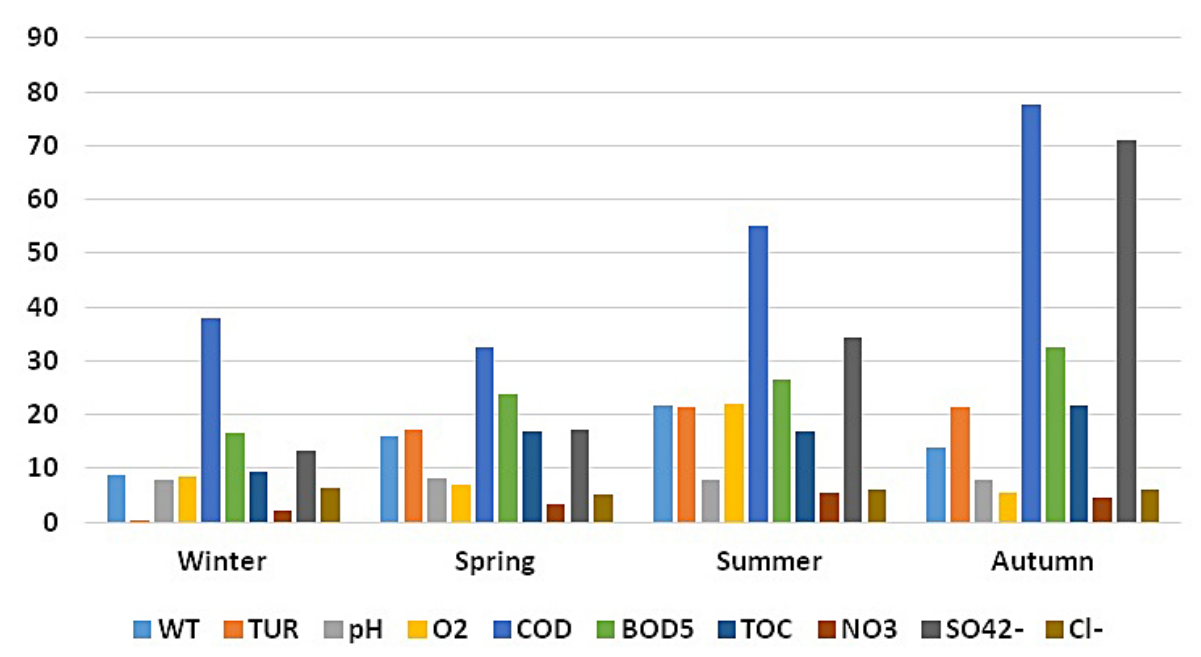

Figure 2. Anual average values of some parameters 


\section{Electrical Conductivity (EC)}

EC variation was in the range of 220.00 $955.00 \mu \mathrm{S} / \mathrm{cm}$ in all four seasons. The lowest value was measured in MB1 station (winter), while the highest one in MB5 station (summer). The average values in winter, spring, summer and autumn were $322.00,371.40,638.60$ and 627.00 $\mu \mathrm{S} / \mathrm{cm}$ respectively, while the annual average with standard deviation was $489.75 \pm 229.91 \mu \mathrm{S} /$ $\mathrm{cm}$. The average value of EC in MB1-MB5 stations were $268.75,357,617,590.5$, and $615.5 \mu \mathrm{S} /$ $\mathrm{cm}$ respectively. There were no values of EC that exceeded the GD161 Regulation. The EC values in the water of Morava e Binçës river were within the recommended values of GD161 Regulation and the water of this river was classified as first class (Fig. 3).

\section{Water Soluble Materials (WSM)}

The WSM variation was in the range of $107.00-550.00 \mathrm{mg} / \mathrm{L}$ in all four seasons. The lowest value was measured in MB1 station (winter), while the highest one in MB5 station (summer). The average values of WSM in winter, spring, summer and autumn were 167.40, 185.60, 322.40 and $345.40 \mathrm{mg} /$ L respectively, while the annual average with standard deviation was $255.20 \pm 131.18$ $\mathrm{mg} / \mathrm{L}$. The average value of EC in MB1-MB5 stations were 38.50, 168.50, 314.75, 304.00, and $350.25 \mathrm{mg} / \mathrm{L}$ respectively. There were no values of WSM that exceeded the GD161 Regulation. The WSM values in the water of Morava e Binçës river were within the recommended values of GD161 Regulation and the water of this river was classified as first class (Fig. 3).

\section{Hydrogen ion concentration $(\mathrm{pH})$}

The $\mathrm{pH}$ variation was in the range of 7.680 8.310. The lowest value was measured in MB3 station (summer), while the highest one in MB1 station (autumn). The average values of $\mathrm{pH}$ in winter, spring, summer and autumn were 7.774, $8.170,7.856$ and 8.012 respectively, while the annual average with standard deviation was $7.953 \pm 0.202$. The average value of $\mathrm{pH}$ in MB1MB5 stations were 8.050, 7.973, 7.853, 7.960 and 7.923 respectively. There were no $\mathrm{pH}$ values that exceeded the GD161 Regulation. The $\mathrm{pH}$ values in the water of Morava e Binçës river were within the recommended values of GD161 Regulation and the water of this river was classified as first class (Fig. 2).

\section{Dissolved Oxygen (DO)}

The DO variation was in the range of $3.600-86.200 \mathrm{mg} / \mathrm{L}$. The lowest value was measured in MB3 station (autumn), while the highest one in MB5 station (summer). The average values of DO in winter, spring, summer and autumn were $8.466,7.106,22.078$ and $5.598 \mathrm{mg} / \mathrm{L}$ respectively, while the annual average with standard deviation was $10.812 \pm 17.870 \mathrm{mg} / \mathrm{L}$. The average value of DO in MB1-MB5 stations were 10.0500, $6.8175,5.0825,6.195$, and $26.1825 \mathrm{mg} / \mathrm{L}$ respectively. Two values of DO were found to be under the recommended norm of GD161 Regulation: $3.600 \mathrm{mg} / \mathrm{L}$ (MB3 in autumn) and $3.940 \mathrm{mg} / \mathrm{L}$ (MB4 in summer). The other values of DO in the water of Morava e Binçës river resulted within the recommended values of the GD161 Regulation and the water of this river was classified as first class (Fig. 2).

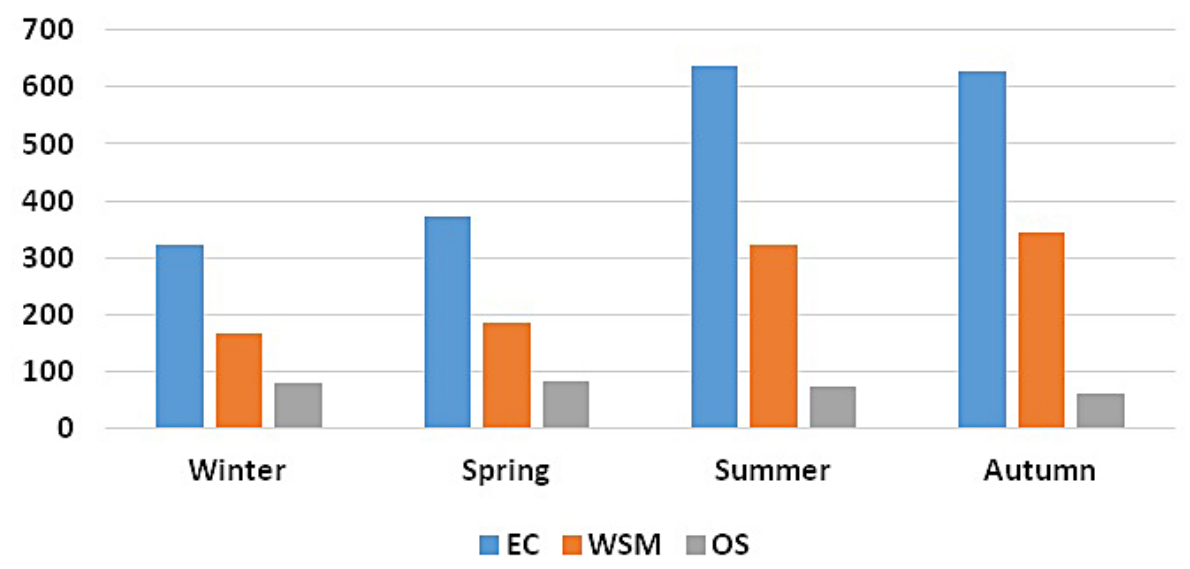

Figure 3. Average annual values of EC, WSM and OS 


\section{Oxygen Saturation (OS)}

The OS variation was in the range of $39.90-92.40 \%$. The lowest value was measured in MB3 station (autumn), while the highest one in MB5 station (spring). The average values of OS in winter, spring, summer and autumn were $78.04,81.06,71.780$ and $59.66 \%$ respectively, while the annual average with standard deviation was $72.635 \pm 16.277 \%$. The average value of OS in MB1-MB5 stations were 86.800, 80.075, $57.500,66.500$, and $72.100 \%$, respectively. The OS values in the water of Morava e Binçës river were within the recommended values of the GD161 Regulation and the water of this river was classified as first class (Fig. 3).

\section{Chemical Oxygen Demand (COD)}

The COD variation was in the range of $18.20-174.00 \mathrm{mg} / \mathrm{L}$. The lowest value was in MB3 station (autumn), while the highest one in MB4 station (autumn). The average values of COD in winter, spring, summer and autumn were $37.840,32.640,55.100$ and $77.660 \mathrm{mg} / \mathrm{L}$ respectively, while the annual average with standard deviation was $50.810 \pm 36.042 \mathrm{mg} / \mathrm{L}$. The average value of COD in MB1-MB5 stations were $8644.30,33.775,68.50,82.75$ and $36.75 \mathrm{mg} / \mathrm{L}$ respectively. Four values of COD exceeded the recommended norm of the GD161 Regulation: $74.000 \mathrm{mg} / \mathrm{L}$ (MB3 in summer), $109.900 \mathrm{mg} / \mathrm{L}$ (MB3 in autumn), $79.000 \mathrm{mg} / \mathrm{L}$ (MB4 in summer) and $174.000 \mathrm{mg} / \mathrm{L}$ (MB4 in autumn). The OCD values in the waters of Morava e Binçës river were slightly over the recommended values of GD161 Regulation and the water of this river was classified as fifth class (Fig. 2).

\section{Biochemical Oxygen demand $\left(\mathrm{BOD}_{5}\right)$}

The $\mathrm{BOD}_{5}$ variation was in the range of $3.300-44.000 \mathrm{mg} / \mathrm{L}$. The lowest value was measured in MB1 station (winter), while the highest one in MB4 station (autumn). The average values of $\mathrm{SHBO}_{5}$ in winter, spring, summer and autumn were $316.480,23.760,26.660$ and 32.540 $\mathrm{mg} / \mathrm{L}$ respectively, while the annual average with standard deviation was $24.860 \pm 11.508 \mathrm{mg} / \mathrm{L}$. The average value of $\mathrm{SHBO}_{5}$ in MB1-MB5 stations were 20.6, 20.7, 31.825, 34.775 and 26.875 $\mathrm{mg} / \mathrm{L}$ respectively. Out of the twenty measured values, fifteen values of $\mathrm{SHBO}_{5}$ were above the recommended value of the GD161 Regulation, which means that the water based on this parameter is too polluted; therefore it was classified as fifth class (Fig. 2).

\section{Total organic carbon (TOC)}

The TOC variation reached $1.200-33.500 \mathrm{mg} / \mathrm{L}$. The lowest value was measured in MB1 station (winter), while the highest one in MB3 station (autumn). The average values of TOC in winter, spring, summer and autumn were 9.460, 17.020, 16.780 and $21.780 \mathrm{mg} / \mathrm{L}$ respectively, while the annual average with standard deviation was $16.260 \pm 10.662 \mathrm{mg} / \mathrm{L}$. The average value of $\mathrm{SHBO}_{5}$ in MB1-MB5 stations were 3.80, 13.20, $23.15,23.575$ and $19.075 \mathrm{mg} / \mathrm{L}$ respectively. The TOC values in the water of Morava e Binçës river were within the recommended values of the GD161 Regulation and the water of this river was classified as first class (Fig. 2).

\section{Nitrates $\left(\mathrm{NO}_{3}{ }^{-}\right)$}

The $\mathrm{NO}_{3}^{-}$variation was in the range of $0.200-11.800 \mathrm{mg} / \mathrm{L}$. The lowest value was measured in MB1 station (autumn), while the highest one in MB4 station (autumn). The average values of $\mathrm{NO}_{3}{ }^{-}$in winter, spring, summer and autumn were $2.280,3.340,5.500$ and $4.620 \mathrm{mg} / \mathrm{L}$ respectively, while the annual average with standard deviation was $3.935 \pm 3.568 \mathrm{mg} / \mathrm{L}$. The average value of $\mathrm{NO}_{3}{ }^{-}$in MB1-MB5 stations were 0.55, 1.525, $4.45,7.95 \mathrm{dhe} 5.30 \mathrm{mg} / \mathrm{L}$ respectively. Only one value of $\mathrm{NO}_{3}{ }^{-}$was above the recommended regulation of GD161: $11.800 \mathrm{mg} / \mathrm{L}$ (MB4 in autumn). The $\mathrm{NO}_{3}{ }^{-}$values in the water of Morava e Binçës river were within the recommended values of the GD161 Regulation and the water of this river was classified as first class (Fig. 2).

\section{Detergents (DET)}

The DET variation reached $0.000-0.500 \mathrm{mg} / \mathrm{L}$. During the whole measurement period, the DET values amouted to $0.000 \mathrm{mg} / \mathrm{L}$, except one value of $0.0500 \mathrm{mg} / \mathrm{L}$ in MB2 station, during summer, which shows that the water was not polluted with detergents, therefore it is belonged to the first class (Fig. 4).

\section{Phosphates $\left(\mathrm{PO}_{4}{ }^{3-}\right)$}

The $\mathrm{PO}_{4}^{3-}$ variation was in the range of $0.100-2.600 \mathrm{mg} / \mathrm{L}$. The lowest value was mea- 
sured in MB1 and MB2 station (winter), while the highest one in MB3 station (autumn). The average values of $\mathrm{PO}_{4}{ }^{3-}$ in winter, spring, summer and autumn were $0.270,0.280,0.500$ and $1.340 \mathrm{mg} / \mathrm{L}$, respectively, while the annual average with standard deviation was $0.598 \pm 0.632 \mathrm{mg} / \mathrm{L}$. The average value of $\mathrm{PO}_{4}^{3-}$ in $\mathrm{MB} 1-\mathrm{MB} 5$ stations were $0.500,0.4475,1.235,0.600$ and $0.405 \mathrm{mg} / \mathrm{L}$, respectively. Only one value of $\mathrm{PO}_{4}{ }^{3-}$ was above the recommended regulation of GD161: $11.800 \mathrm{mg} / \mathrm{L}$ (MB4 in autumn). Fourteen values of $\mathrm{PO}_{4}^{3-}$ were above the recommended regulations of GD161, which shows that the water of the river were polluted with this pollutant. The $\mathrm{PO}_{4}^{3-}$ values of Morava e Binçës river were not in proportion with the recommended values of the GD161 Regulation and the water of this river classified lower than the fifth class (Fig. 4).

\section{Ammonium ion $\left(\mathrm{NH}_{4}^{+}\right)$}

The $\mathrm{NH}_{4}^{+}$variation was in the range of $0.240-1.600 \mathrm{mg} / \mathrm{L}$. The lowest value was measured in MB1 (winter), while the highest one in MB6 station (autumn). The average values of $\mathrm{NH}_{4}^{+}$in winter, spring, summer and autumn were $0.742,0.882,0.938 \mathrm{dhe} 0.926 \mathrm{mg} / \mathrm{L}$, respectively, while the annual average with standard deviation was $3.935 \pm 3.568 \mathrm{mg} / \mathrm{L}$. The average value of $\mathrm{NH}_{4}^{+}$in MB1-MB5 stations were 0.1700, $0.7775,1.5225,1.0425$ and $0.6675 \mathrm{mg} / \mathrm{L}$ respectively. Only one value of $\mathrm{PO}_{4}{ }^{3-}$ was above the recommended regulation of GD161: $11.800 \mathrm{mg} / \mathrm{L}$ (MB4 in autumn). Generally, the $\mathrm{NH}_{4}^{+}$values in the water of Morava e Binçës river were within the reccomended values of the GD161 Regulation and the water of this river was classified as the second category (Fig. 4).

\section{Nitrites $\left(\mathrm{NO}_{2}{ }^{-}\right)$}

The $\mathrm{NO}_{2}^{-}$variation was in the range of $0.010-1.100 \mathrm{mg} / \mathrm{L}$. The lowest value was measured in MB1 (winter, spring and autumn), while the highest one in MB4 station (autumn). The average values of $\mathrm{NO}_{2}{ }^{-}$in winter, spring, summer and autumn were $0.074,0.248,0.844$ and 0.460 $\mathrm{mg} / \mathrm{L}$, respectively, while the annual average with standard deviation was $0.407 \pm 0.353 \mathrm{mg} / \mathrm{L}$. The average value of $\mathrm{NO}_{2}{ }^{-}$in MB1-MB5 stations were $0.350,0.2575,0.530,0.5725$ and $0.4925 \mathrm{mg} / \mathrm{L}$, respectively. Ten values of $\mathrm{NO}_{2}^{-}$were above the recommended values of theGD161 Regulation, which indicates that the waters were polluted with this compound, therefore they were ranked lower than the fifth category (Fig. 4).

\section{Sulphates $\left(\mathrm{SO}_{4}{ }^{2-}\right)$}

The $\mathrm{SO}_{4}^{2-}$ variation was in the range of $4.00-204.00 \mathrm{mg} / \mathrm{L}$. The lowest value was measured in MB1 (winter), while the highest one in MB5 station (autumn). The average values of $\mathrm{SO}_{4}^{2-}$ in winter, spring, summer and autumn were $3.264,17.322,34.456$ and $70.968 \mathrm{mg} / \mathrm{L}$ respectively, while the annual average with standard deviation was $34.003 \pm 48.856 \mathrm{mg} / \mathrm{L}$. The average value of $\mathrm{SO}_{4}^{2-}$ in the stations MB1-MB5 were $8.8400,10.0276,22.125,36.3750$ and $95.4250 \mathrm{mg} / \mathrm{L}$, respectively. The $\mathrm{SO}_{4}{ }^{2-}$ values in the water of Morava e Binçës river were within the recommended values of the GD161 Regu-

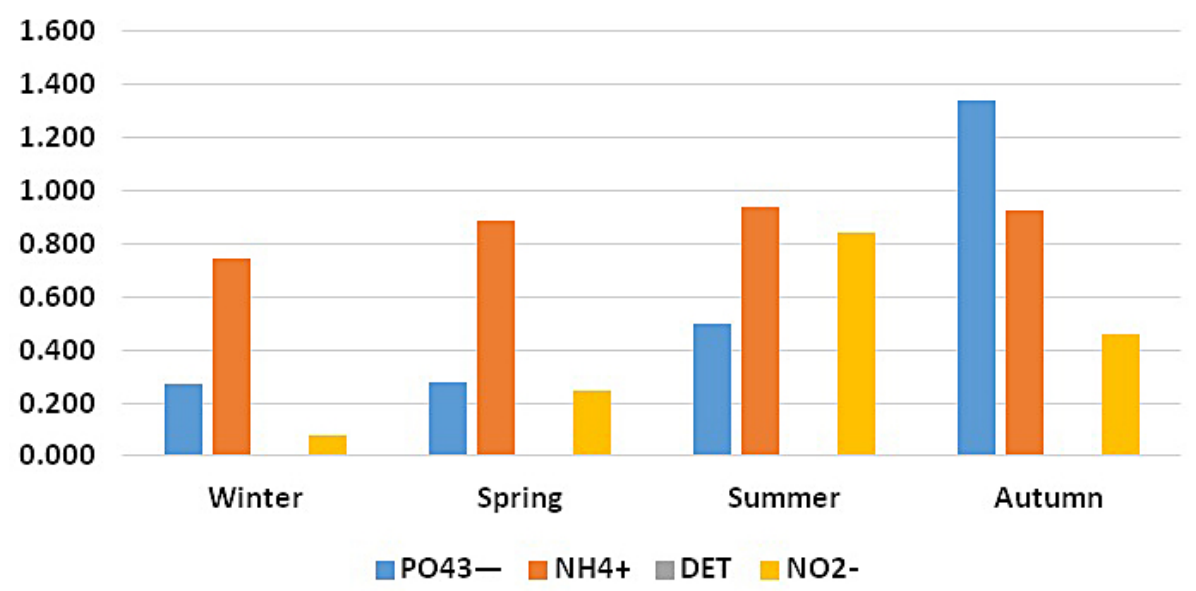

Figure 4. Annual average values of phosphates, ammoniium ion, detergents and nitrites 
lation and the water of this river was classified as first class (Fig. 2).

\section{Chlorides $\left(\mathrm{Cl}^{-}\right)$}

The $\mathrm{Cl}^{-}$variation was in the range of $1.100-10.650 \mathrm{mg} / \mathrm{L}$. The lowest value was measured in MB1 (winter), while the highest one in MB3 station (winter). The average values of $\mathrm{Cl}^{-}$in winter, spring, summer and autumn were 6.468, $5.150,5.934$ and $6.018 \mathrm{mg} / \mathrm{L}$ respectively, while the annual average with standard deviation was $34.003 \pm 48.856 \mathrm{mg} / \mathrm{L}$. The average value of $\mathrm{Cl}^{-}$in MB1-MB5 stations were 2.0500, 4.765, 8.7300, 7.4550 and $6.6875 \mathrm{mg} / \mathrm{L}$ respectively. The $\mathrm{Cl}^{-}$ values in the water of Morava e Binçës river were within the recommended values of the GD161 Regulation and the water of this river was classified as first class (Fig. 2).

Correlation coefficients of physico-chemical parameters of the Morava e Binçës river

The correlation coefficients between the parameters of the waters in the Morava River in Binçë are shown in Table 1. The results show that some values of correlation coefficient have been more significant. The most significant positive correlations were observed between: ECWSM $(r=0.9693)$, BOD $_{5}$-TOC $(r=0.9150)$, and TUR-BOD 5 ( $r=0.8425)$. The most emphasized negative correlation was noted between: OS-TOC $(r=-0.8182)$, OS-phosphates $(r=-0.7668)$, TUROS $(r=-0.7148)$, and WSM-OS $(r=-0.7060)$.

\section{Water quality assessment of Morava e Binçës river with WQI}

The WQI calculation was done by using Water Quality Index Desktop computer program which was developed in 2017 by the authors [Ramadani et al., 2017] according to the literature [CCME, 2001]. The frequency results for the F1, F2, F3 frequencies and WQI for five stations are given in Table 2 and Figure 5.

In MB1 station, the WQI value reached 88, since 3 parameters $\left(\mathrm{BOD}_{5}\right.$ phosphates and nitrites) and 5 tests have failed: 1 test of $\mathrm{BOD}_{5} ; 3$ tests of phosphates; and 1 test of nitrites. In MB2 station, WQI value reached, 86 since 3 parameters $\left(\mathrm{BOD}_{5}\right.$, phosphates and nitrites) and 7 tests have failed: 3 tests of $\mathrm{BOD}_{5}$; 3 tests of phosphates; and 1 test of nitrites. In MB3 station, the WQI amounted to 67 with 7 failed parameters ( TUR, $\mathrm{DO}, \mathrm{COD}, \mathrm{BOD}_{5}$, TOC, phosphates and nitrites) and 16 tests: 2 tests of TUR; 1 test of DO; 2 tests of COD; 3 tests of $\mathrm{BOD}_{5} ; 1$ test of TOC; 4 tests of phosphates; and 3 tests of nitrites. In MB4 station, the WQI value reached 65 , since 8 parameters: (TUR, DO, COD, BOD 5 , TOC, nitrates, phosphates and nitrites) and 17 tests have failed: 3 TUR tests; 1 test of DO; 2 tests of COD; 4 tests of $\mathrm{BOD}_{5} ; 1$ test of TOC; 1 test of nitrates; 3 tests of phosphates; and 2 tests of nitrites. In MB5 station, the WQI value reached 82 , because 4 parameters: (TUR, $\mathrm{BOD}_{5}$, phosphates and nitrites) and 9 tests have failed: 1 test of TUR; 4 tests of $\mathrm{BOD}_{5} ; 2$ tests of phosphates; and 2 tests of nitrites.

Table 1. Correlation of the parameters

\begin{tabular}{|c|c|c|c|c|c|c|c|c|c|c|c|c|c|c|c|c|c|}
\hline Correlations & WT & TUR & EC & WSM & $\mathrm{pH}$ & От & os & COD & $\mathrm{BOD}_{5}$ & TOC & $\mathrm{NO}_{3}{ }^{-}$ & DET & $\mathrm{PO}_{4}{ }^{3-}$ & $\mathrm{NH}_{4}^{+}$ & $\mathrm{NO}_{2}^{-}$ & $\mathrm{SO}_{4}{ }^{2-}$ & $\mathrm{Cl}^{-}$ \\
\hline WT & 1.0000 & & & & & & & & & & & & & & & & \\
\hline TUR & 0.4390 & 1.0000 & & & & & & & & & & & & & & & \\
\hline EC & 0.4254 & 0.6464 & 1.0000 & & & & & & & & & & & & & & \\
\hline WSM & 0.3324 & 0.6098 & 0.9693 & 1.0000 & & & & & & & & & & & & & \\
\hline $\mathrm{pH}$ & 0.1832 & 0.0779 & -0.3403 & -0.3251 & 1.0000 & & & & & & & & & & & & \\
\hline DO & 0.2471 & -0.1597 & 0.3835 & 0.3022 & -0.2296 & 1.0000 & & & & & & & & & & & \\
\hline os & -0.0887 & -0.7148 & -0.6809 & -0.7060 & 0.2393 & 0.2943 & 1.0000 & & & & & & & & & & \\
\hline COD & 0.1181 & 0.7196 & 0.5558 & 0.5426 & -0.0997 & -0.1768 & -0.7311 & 1.0000 & & & & & & & & & \\
\hline $\mathrm{BOD}_{5}$ & 0.3859 & 0.8425 & 0.7365 & 0.7246 & 0.0444 & -0.1621 & -0.8190 & 0.7163 & 1.0000 & & & & & & & & \\
\hline TOC & 0.2806 & 0.8293 & 0.7207 & 0.7034 & -0.0273 & -0.1647 & -0.8182 & 0.5379 & 0.9150 & 1.0000 & & & & & & & \\
\hline $\mathrm{NO}_{3}{ }^{-}$ & 0.3253 & 0.6407 & 0.8217 & 0.7871 & -0.2594 & 0.3475 & -0.5067 & 0.5737 & 0.6630 & 0.6195 & 1.0000 & & & & & & \\
\hline DET & 0.4575 & -0.1195 & -0.1042 & -0.1098 & -0.0617 & -0.0600 & 0.2309 & -0.0216 & -0.0749 & -0.2088 & -0.2002 & 1.0000 & & & & & \\
\hline $\mathrm{PO}_{4}{ }^{3-}$ & 0.0280 & 0.5097 & 0.5477 & 0.5689 & -0.0737 & -0.2530 & -0.7668 & 0.7245 & 0.6335 & 0.5668 & 0.2183 & 0.0009 & 1.0000 & & & & \\
\hline $\mathrm{NH}_{4}^{+}$ & 0.2694 & 0.4799 & 0.5680 & 0.4862 & -0.2209 & -0.1258 & -0.6413 & 0.4648 & 0.6728 & 0.6743 & 0.4791 & -0.0855 & 0.5584 & 1.0000 & & & \\
\hline $\mathrm{NO}_{2}^{-}$ & 0.7020 & 0.6320 & 0.8549 & 0.8056 & -0.2564 & 0.3239 & -0.5152 & 0.4680 & 0.6118 & 0.5499 & 0.7549 & 0.1091 & 0.3158 & 0.4687 & 1.0000 & & \\
\hline $\mathrm{SO}_{4}{ }^{2-}$ & 0.0408 & 0.2597 & 0.6962 & 0.8174 & -0.1960 & 0.3512 & -0.3731 & 0.2028 & 0.3981 & 0.4157 & 0.5800 & -0.1374 & 0.3010 & 0.0501 & 0.4672 & 1.0000 & \\
\hline $\mathrm{Cl}^{-}$ & 0.0327 & 0.3623 & 0.6469 & 0.6577 & -0.4619 & 0.0743 & -0.6242 & 0.3763 & 0.6224 & 0.6611 & 0.6395 & -0.2276 & 0.3612 & 0.7380 & 0.4139 & 0.4445 & 1.0000 \\
\hline
\end{tabular}


Table 2. The calculated values of F1, F2, F3 and WQI for five sampling stations

\begin{tabular}{|c|c|c|c|c|}
\hline Stations & F1 & F2 & F3 & WQI \\
\hline MB1 & 17.64706 & 7.352942 & 5.318159 & 88 \\
\hline MB2 & 17.64706 & 10.29412 & 9.483876 & 86 \\
\hline MB3 & 41.17647 & 23.52941 & 31.89383 & 67 \\
\hline MB4 & 47.05882 & 26.47059 & 24.69702 & 65 \\
\hline MB5 & 23.52941 & 13.23529 & 14.03916 & 82 \\
\hline \multicolumn{4}{|r}{ Average WQI } \\
\hline
\end{tabular}

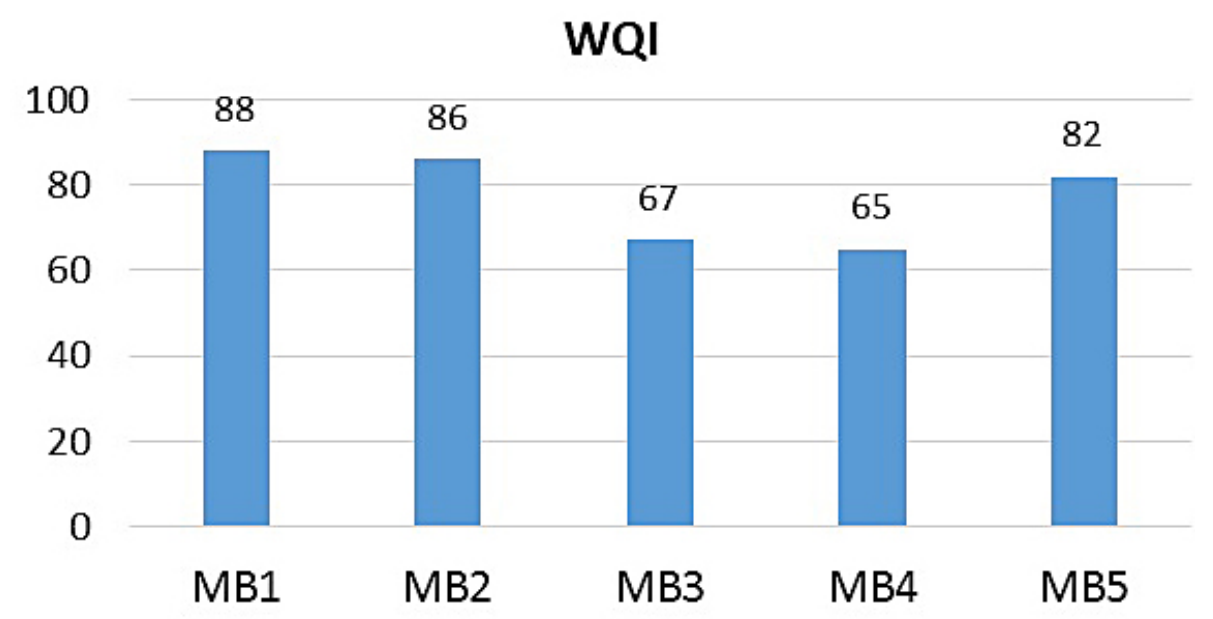

Figure 5. Values of WQI in MB1, MB2, MB3, MB4 and MB5 stations

The results show that the water of MB1 station has better water quality with a WQI 88 value and is ranked in good category, while the lowest water quality was found on MB4 station with a value of WQI 65 as a part of fair category. Finally, the average WQI was calculated for the whole measuring period and it resulted with a value of 77.60 showing that the water of Morava e Binçës river fits in the fair category.

\section{CONCLUSIONS}

1. This article analysed the waters of Morava e Binçës by using the physicochemical parameters, in four seasons of 2017. The values of measured parameters were compared with the Romanian Republic standards for the assessment of the ecological status of surface waters (GD161). The following conclusions can be drawn from the research and the discussion of results:

2. The waters of Morava e Binçës were more loaded with pollution at MB3, MB4 and MB5 sampling stations, but the pollutions are not alarming and the river represents a convenient aquasystem for the life of living beings and economic activity.

3. The values of parameters such as: WT, TUR, EC, WSM, pH, DO, OS, TOC, nitrates, DET, ammonium ion, sulfates and chlorides were in consistency with the GD161 recommendations and are categorized as first class;

4. Some of the parameters value such as: COD, $\mathrm{BOD}_{5}$, phosphates, nitrites exceeded the recommended value of the GD161 regulation and were categorized as of fifth category;

5 . The highest positive correlation was found between: EC-WSM $(r=0.9693), \mathrm{BOD}_{5}$-TOC $(r$ $=0.9150)$, whereas the negative one was found between: ng. $\mathrm{O}_{2}$-TOC $(r=-0.8182)$ and ng. $\mathrm{O}_{2}-$ phosphates $(r=-0.7668)$;

6. The Water Quality Index Desktop software is used as a highly efficient tool for calculating WQI according to the guidelines of the Canadian Environmental Ministry;

7. On the basis of the WQI calculations, it was shown that the best quality was found at the MB1 station with the WQI 88 value (good category), the lowest water quality was found at MB4 station with a value of WQI 65 (the category: fair), while the average WQI for the 
entire measurement period was 77.60 (the fair category);

8. We propose that the authorities and state institutions should support the river water monitoring as an effective measure to examine their ecological status and protection against pollution.

\section{REFERENCES}

1. Anbarasu K., Anbuselvan G. 2017. Physico-chemical parameter analysis of water in Musiri Taluk, Tamil Nadu, India, World News of Natural Sciences (WNOFNS), (6) 36-43.

2. Barakat A., Baghdadi M. E., Rais J., Nadem S. 2012. Assessment of heavy metal in surface sediments of Day river at Beni-Mellal Region, Morocco. Res. J. Environ. Earth Sci., 4: 797-806.

3. Durmishi H. B. 2005. Determination of pollution degree of the river Shkumbin (Pena) with heavy metals and other effluent with spectrometric method and ,stripping” voltammetry, Master's Thesis, University of Prishtina, Faculty of Mathematics and Natural Sciences, Department of Chemistry, Prishtina, Kosova, p. 9.
4. CCME. 2001. Canadian water quality guidelines for the protection of aquatic life: CCME Water Quality Index 1.0 User's Manual. Canadian Council of Ministers of the Environment.

5. Durmishi H. B., Ismaili M., Shabani A., Abduli Sh. 2012. Drinking Water Quality Assessment in Tetova Region, American Journal of Environmental Sciences, 8(2), 162-169.

6. Ramadani E., Memeti M., Durmishi H. B. 2017. Water Quality Index: A New Automated Way of Measuring the Quality, International Journal on Information Technologies \& Security, 3, 43-52.

7. Krishnan R. R., Dharmaraj K., Kumari B. D. R. 2007. A comparative study on the physicochemical and bacterial analysis of drinking, borewell and sewage water in the three different places of Sivakasi, J. En. Biol. 28, 105-108.

8. Ismaili M., Durmishi B. 2006. Society and Management of Environment, University Book, South East European University, Tetova, R. of Macedonia, 21.

9. Ministry of Environment and Spatial Planning of Kosova (MESP). Environmental Protection Agency 2015. Report on the State of Water. Prishtinë, 42.

10. Ministry of Environment and Spatial Planning. Department of Waters (MMPH) 2010. Hydrography of Kosova's Rivers, Republic of Kosova, 8-11. 